\title{
>>venture >>: Support for Early Stage Start-ups and Potential Entrepreneurs
}

\author{
Lukas Kauz, Communication >>venture > ${ }^{\star}$
}

\begin{abstract}
Swiss-wide business plan competition, is an ideal partner for young start-ups and entrepreneurs. For the upcoming tenth anniversary edition the competition will receive an update. Building upon a successful base of the past nine editions and equipped with contemporary networking events and more know-how transferring seminars, >>venture >> will fit even better into the Swiss start-up ecosystem.
\end{abstract}

Keywords: Business plan $\cdot$ Coaching $\cdot$ Entrepreneur $\cdot$ Start-ups $\cdot$ venture

\begin{abstract}
">>venture $>>$ can look back on a story of huge success", notes Dr. Thomas Knecht, former director of McKinsey \& Company Switzerland and founder of the $>>$ venture >> competition, "being an innovative and pioneering start-up itself back in 1996, >>venture >> has evolved to the leading start-up competition in Switzerland", he continues. "Our formula for success is based on a network of strong partners, on know-how transfer via experienced coaches and experts and on a fair jury process in which every team gets its chance", Dr. Knecht discloses.
\end{abstract}

\section{Success Stories}

The formula worked: More than 2000 teams have participated in $>>$ venture $>>$ since 1998, and they have created more than 5000 stable and highly qualified jobs. Following the footsteps of $>>$ venture $>>$ winners leads to successful companies.

${ }^{*}$ Correspondence: >>venture >> Office

Rütistrasse 14

$\mathrm{CH}-8952$ Schlieren

Tel. +410583322330

E-mail: office@venture.ch
Molecular Partners, winner in 2004, announced that they have entered into a USD one billion research collaboration and licensing agreement with Roche to discover, develop and commercialize several proprietary therapeutics for the treatment of cancer.

Covagen, >>venture > > winner in 2006, has secured CHF 42 million in tranches in a Series B financing.

Glycart, one of the winners in 2000, was acquired by Roche for 235 million US dollars in 2005. Last November, Roche announced that they gained FDA approval for a new drug against chronic lymphocytic leukemia; this drug was discovered by Glycart.

In August 2013 St. Jude Medical acquired Endosense, a winner in 2004, for up to CHF 309 million.

And last but not least the first $>>$ venture $>>$ winner Sensirion has grown steadily since the team's participation in 1998 and currently employs over 550 employees and is generating revenues of CHF 150 million in 2013.

\section{Anniversary in 2015: $\gg$ venture $>2.0$}

During the last 18 years the Swiss startup scene has changed a lot. More and more people and institutions are interested in entrepreneurship. Many young scientists prefer to build up their own company instead of going for a career in a big corporation or a university. The start-up ecosystem grows. Therefore, $>>$ venture $>>$ will adapt in order to stay the ideal supporter for early stage start-ups and potential entrepreneurs. "We decided to make >>venture $>>$ even more attractive", Dr. Knecht outlines, "we will change to an annual schedule of our competition instead of the biannual model we have had so far." But that is not the only change for the upcoming 2015 edition starting at the beginning of February and ending in June 2015. Dr. Knecht closes: "We cannot reveal too much at this stage, but I can promise that there will be an even tighter integration into the start-up ecosystem with more possibilities to network and get to know coaches, a bigger presence of investors at an early stage and attractive prizes not only in terms of money..."

\section{What is $>>$ venture $>>$ ?}

$>>$ venture $>>$ is an initiative of the ETH Zurich, Knecht Holding, the innovation promotion agency CTI and McKinsey \& Company, Switzerland. As the leading Swiss-wide business plan competition >>venture $>$ supports young entrepreneurs in founding a company. The competition aims to put to use untapped innovation potential by encouraging young entrepreneurs to develop a business idea. A number of renowned companies from the Swiss industry and commerce sponsor the competition.

Experienced coaches support competition participants in the development of their business idea, the preparation of their business plans, and in the search for suitable partners and the necessary capital. Participants also receive feedback from the team of highly qualified jurors. The jurors (approximately 80 experts) belong to one of two groups: entrepreneurs, who evaluate the formal and business aspects of an idea, and investors, who evaluate its financial attractiveness.

Participants receive additional support in the form of various events, e.g. a series of seminars, special workshops and networking platforms.

>>venture >> is targeting budding entrepreneurs in Switzerland who have innovative business ideas. Participants may enter the competition as individuals or as a team. 
In addition to the prize money for the most successful teams, $>>$ venture $>>$ guarantees:

- Know-how: >>venture>> provides access to experienced coaches who support young entrepreneurs in the preparation of their business idea and their business plan.

- Network: >>venture >> offers new and valuable contacts between young entrepreneurs, to $>>$ venture $>>$ capitalists and to management personalities from business and research.

- Publicity: the media will follow »venture» closely. Participating teams have valuable publicity for their future company.

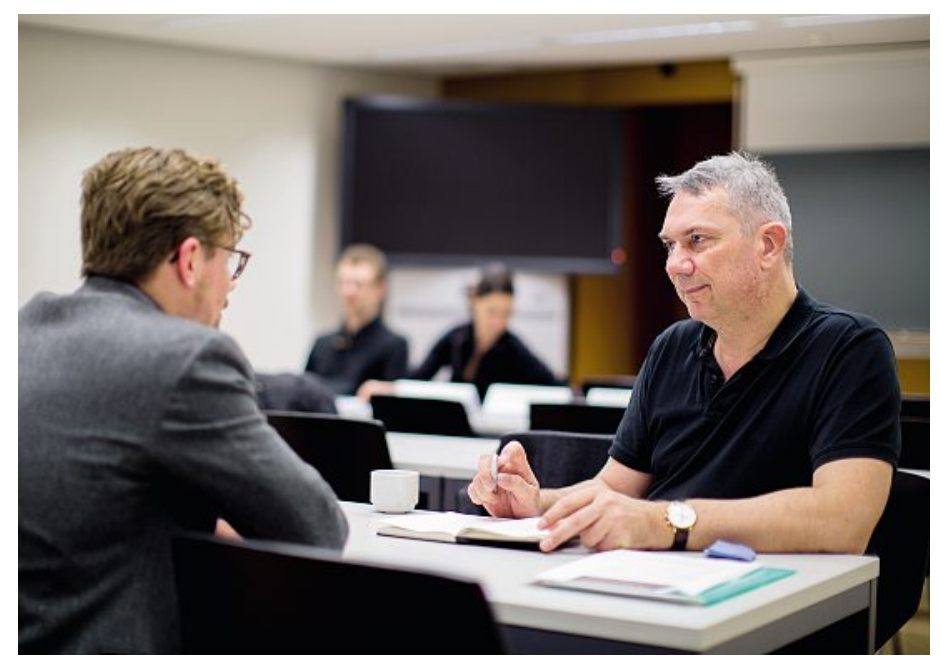

Fig. 1. Know-how transfer: >>venture >> coach Jan Fülscher in action.

66 Imagination, ideas, and the will to take risks are at the heart of discoveries in science. These characteristics combined with entrepreneurial talent are essential requirements to master the step of bringing new applications and products to the market.

More often than not, we find these elements in individuals and small groups. Flexibility and the drive to succeed are their characteristics. Start-ups are the answer. Having been rare in Switzerland some 20 years ago, start-ups today are key elements of progress, and the national economic future would look bleak if they were absent.

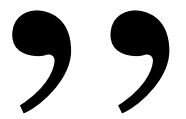

Peter Kündig, Emeritus Professor of Chemistry, University of Geneva President of the Swiss Chemical Society 